\title{
IMPLEMENTASI MANAJEMEN KELAS DALAM KEGIATAN BELAJAR MENGAJAR DI TAMAN KANAK- KANAK NEGERI 08 PENATOI KOTA BIMA
}

\author{
Run Alfisah, Lukman \\ Email: putrasanggar231@gmail.com
}

\section{ABSTAKSI}

Tujuan penelitian ini adalah; 1) untuk menjelaskan implementasi manajemen kelas dalam kegiatan belajar mengajar di Taman KanakKanak Negeri 08 Penatoi Kota Bima, 2) untuk mengetahui kendala yang dihadapi dalam implementasi manajemen kelas dalam kegiatan belajar mengajar di Taman Kanak-Kanak Negeri 08 Penatoi Kota Bima. Untuk memperoleh data dalam penelitian ini peneliti menggunakan metode penelitian kualitatif yaitu penelitian berangkat dari sebuah teori menuju data dan berakhir pada penerimaan atau penolakan terhadap teori yang digunakan, dan data yang di hasilkan melalui observasi, wawancara dan dokumentasi. Penelitian ini dilaksanakan di Taman Kanak-Kanak Negeri 08 Penati Kota Bima Hasil penelitian menunjukkan bahwa implementasi manajemen di Taman Kanak-Kanak Negeri 08 Penatoi Kota Bima dilakukan dengan tahap awal yaitu perencanaan program yang terdiri dari PROTA, PROSEM, RPPM, RPPH yang berisikan Tema dan Sub Tema, Kompetensi Dasar (KD), Materi, dan rencana kegiatan yang didalam terdapat kegiatan Pembuka, Inti, dan Penutup, dan terakhir melakukan evaluasi terkait kegiatan yang dilakukan. Dalam hal ini terdapat juga kendala yang di alami guru dalam implementasi manajemen kelas dalam kegiatan belajar mengajar di Taman Kanak-Kanak Negeri 08 Penatoi Kota Bima ialah Faktor Guru, Faktor peserta didik, dan kurangnya media ajar atau Alat Peraga Edukatif (APE).

Kata Kunci: Implementasi, Manajemen, Belajar Mengajar.

\section{PENDAHULUAN}

Pendidikan merupakan kebutuhan dasar manusia yang harus terpenuhi, maka dari itulah pemerintah mengatur hal ini sedemikian rupa, baik dalam aturan undang-undang maupun kebijakan agar setiap individu berhak mendapatkan pendidikan. Pendidikan Anak 
Usia Dini adalah suatu upaya pembinaan yang ditujukan kepada anak sejak lahir sampai dengan usia enam tahun yang dilakukan melalui pemberian rangsangan pendidikan untuk membantu pertumbuhan dan perkembangan jasmani dan rohani agar anak memiliki kesiapan dalam memasuki pendidikan lebih lanjut.

Dalam UU No.20 Tahun 2003 tentang Sistem Pendidikan Nasional, telah dinyatakan bahwa;

Pendidikan terdiri dari pendidikan Anak Usia Dini, Sekolah Dasar, Pendidikan Menengah (SMP), Pendidikan tinggi. Pendidikan dimulai sejak sedini mungkin (PAUD). PAUD dapat diselenggarkan melalui jalur formal, informal maupun non formal, dari segi formal seperti TK, RA, BA atau bentuk sederajat yang lainnya. Pada jalur Non formal di antaranya yaitu KB, TPA atau yang lain yang sejenis dan yang informal seperti pendidikan dari dalam atau pendidikan yang paling berpengaruh bagi anak seperti pendidikan keluarga atau pendidikan yang diadakan oleh lingkungan sekitar ${ }^{1}$.

Dalam konteks Negara Indonesia, pendidikan merupakan hak dan kewajiban bagi seluruh warga negara sebagaimana diamanatkan dalam Undang-Undang Dasar 1945, khususnya pada pasal 31 bahwa; (1) setiap warga negara berhak mendapatkan pendidikan, (2) setiap warga negara wajib mengikuti pendidikan dasar dan pemerintah wajib membiayainya, dan (3) pemerintah mengusahakan dan menyelenggarakan satu sistem pendidikan nasional yang meningkatkan keimanan dan ketaqwaan serta akhlak mulia dalam rangka mencerdaskan kehidupan bangsa yang diatur didalam undang-undang. Oleh karena itu, pendidikan harus menjadi prioritas utama dalam proses keseluruhan pembangunan nasional. ${ }^{22}$

Pendidikan dikatakan berkualitas jika proses pembelajarannya berlangsung secara menarik dan menantang, sehingga peserta didik dapat belajar sebanyak mungkin melalui proses belajar yang berkelanjutan. Proses pendidikan yang berkualitas akan menghasilkan pendidikan yang berkualitas pula, dengan demikian akan semakin meningkatkan kualitas kehidupan bangsa ${ }^{33}$.

${ }^{1}$ Depdiknas, Undang-Undang Sistim Pendidikan Nasional, (Jakarta : Depdiknas, 2005), hal.22.

${ }^{2}$ Agustinus Hermino, Kepemimpinan Pendidikan di Era Globalisasi, (Yogyakarta: Pustaka Pelajar, 2014), hal.2.

${ }^{3}$ Radno Harsanto, Pengelolaan Kelas yang Dinamis, (Yogyakarta: KANISIUS, 2007), hal.3. 
Pendidikan yang berkualitas merupakan hal yang sangat penting dalam meningkatkan kualitas peserta didik. Dalam hal ini kualitas dari sarana dan prasarana sangat berpengaruh dalam hasil yang akan dicapai. Salah satu sarana yang sangat diperlukan adalah kelas. Untuk menjadikan kelas lebih maksimal dalam penggunaannya perlu adanya manajemen atau pengelolaan yang baikyang perlu dilakukan. Manajemen kelas adalah segala kegiatan guru di kelas yang menciptakan dan mempertahankan kondisi yang optimal dalam terjadinya proses belajar. Dengan demikian, efektifitas pelaksaanaan manajemen kelas sangat bergantung kepada guru karena guru mempunyai tugas dan tanggung jawab dalam mengelola kelas dengan baik agar pembelajaran dapat berlangsung secara efektif dan efisien, sehingga dapat tercipta suasana kelas yang menyenangkan bagi peserta didik dalam melangsungkan kegiatan pembelajaran.

Sebagai pengelola kelas, guru hendaknya dapat mengelola dengan baik, karena kelas adalah tempat berhimpun semua anak didik dan guru dalam rangka menerima bahan pelajaran dari guru. Kelas yang dikelola dengan baik akan menunjang jalannya interaksi edukatif. Sebaliknya, kelas yang tidak dikelola dengan baik akan menghambat kegiatan pengajaran. Anak didik tidak mustahil akan merasa bosan untuk tinggal lebih lama di kelas. Hal ini akan berakibat mengganggu jalannya proses interaksi edukatif ${ }^{44}$.

Sukses tidaknya pengajaran tergantung dari kemampuan guru dalam mempertimbangkan unsur siswa, siswa adalah manusia yang harus diperlakukan apa adanya. Siswa juga dipandang sebagai mahluk yang unik dan memiliki karakteristik sendiri yang antara seorang siswa dengan lainnya jelas tidak sama, yang secara wajar sedang dalam masa pertumbuhan dan perkembangan. Sehingga proses pendidikan yang baik akan membantu proses pertumbuhan dan perkembangan masingmasing siswa ${ }^{55}$.

Berdasarkan hasil observasi di TK Negeri 08 Penatoi Kota Bima dapat diketahui bahwa Penataan Manajemen Kelas di TK Negeri 08

${ }^{4}$ Moh. Roqib \& Nurfuadi, Kepribadian Guru, (Purwokerto: STAIN Purwokerto Press, 2011), hal. 110.

${ }^{5}$ Suharsimi Arikunto, Organisasi dan Administrasi Pendidikan Teknologi dan Kejuruan, (Jakarta: PT Rajagrafindo Persada, 2013), hal. 61.

Jurnal Pelang̉i Jurnal pemikiran dan penelitian pendidkan Islam anak Usia Dini 
Penatoi Kota Bima terlihat cukup baik misalnya kepala sekolah memilih guru untuk menjadi guru kelas dan guru pendamping. Guru kelas bertanggung jawab sepenuhnya dari mulai pembelajaran, administrasi, sampai pembelajaran berahir. Sedangkan guru pendamping bertanggung jawab dalam membantu semua kegiatan yang ada di kelas. Kedua yaitu pembuatan Rencana Program Pembelajaran Mingguan (RPPM) setelah RPPM di ACC lalu pembuatan Rencana Program Pembelajaran Harian (RPPH) selanjutnya guru melakukan persiapan mengajar. Namun prakteknya, sebagian guru yang mengajar di TK Negeri 08 Penatoi Kota Bima kurang memahami dalam menerapkan manajemen kelas misalnya dalam mengajar, guru kelas membebankan jam mengajar terlalu banyak pada guru pendamping, siswa jarang melakukan kegiatan belajar di luar kelas sehingga berakibat menurunnya minat dan motivasi anak misalnya anak-anak kurang fokus mendengar apa yang sampaikan, anak-anak cenderung bermain-main dan sebagainya ${ }^{66}$. Dari uraian diatas, penulis tertarik untuk meneliti tentang" Implementasi Manajemen Kelas Dalam Kegiatan Belajar Mengajar di TK Negeri 08 Penatoi Kota Bima”.

\section{A. Implementasi}

\section{Pengertian Implementasi}

Pelaksanaan atau implementasi dalam Kamus Besar Bahasa Indonesia diartikan sebagai pelaksanaan atau penerapan. ${ }^{7}$ Sedangkan menurut Fullan dalam Abdul Majid implementasi adalah suatu prooses peletakan dalam praktik tentang suatu ide, program atau seperangkat aktivitas baru bagi orang lain dalam mencapai atau mengharapkan suatu perubahan. ${ }^{8}$

Implementasi menurut Muhammad Joko Susila bahwa implementasi merupakan suatu penerapan ide-konsep, kebijakan, atau inovasi dalam suatu tindakan praktis sehingga mendapatkan dampak, baik berupa perubahan pengetahuan, keterampilan, maupun sikap. ${ }^{9}$

${ }^{6}$ Observasi di TK Negeri 08 Penatoi Kota Bima Tanggal 13 Mei 2019, jam 08.20 Wita.

${ }^{7}$ Heppy Elrais, Kamus Ilmiah Populer,(Bandung: Interes Media, 2015), hal.30.

${ }^{8}$ Abdul Majid, Implementasi Kurikulum 2013 Kajian Teoritis dan Praktis, (Bandung: Interes Media, 2014), hal. 6.

${ }^{9}$ Muhammad Fathurrohman dan Sulistyorini, Implementasi manajemen Peningkatan Mutu Pendidikan Islam Peningkatan Lembaga Pendidikan Islam Secara Holistik, (Yogyakarta: Teras, 2012), 


\section{Tahap-Tahap Implementasi}

a. Pengembangan program, yaitu mencakup program tahunan, semester, bulanan, mingguan dan harian. Selain itu juga ada program bimbingan dan konseling atau program remedial.

b. Pelaksanaan pembelajaran, pada hakekatnya, pembelajaran adalah proses interaksi antara peserta didik dengan lingkungannya sehingga terjadi proses perubahan perilaku kearah yang lebih baik.

c. Evaluasi, yaitu proses yang dilaksanakan sepanjang proses pelaksanaan kurikulum atau semester serta penilaian akhir formatif atau sumatif mencakup penilaian keseluruhan secara utuh untuk keperluan evaluasi pelaksanaan kurikulum. ${ }^{10}$

\section{B. Manajemen Kelas}

\section{Pengertian Manajemen Kelas}

Guru memiliki peran yang sangat besar dalam menentukan kuantitas dan kualitas pembelajaran. Pengelolaan kelas merupakan salah satu aspek pembelajaran yang harus dikuasai guru agar siswa dapat belajar dengan optimal. Pengelolaan kelas yang baik akan membuat suasana kelas menjadi kondusif untuk proses belajar mengajar, sehingga tujuan pembelajaran dapat tercapai.

Mendukung hal itu Mulyadi mengemukakan manajemen kelas adalah seperangkat kegiatan untuk mengembangkan tingkah laku siswa yang diinginkan dan mengurangi atau meniadakan tingkah laku yang tidak diinginkan, mengembangkan hubungan interpersonal dan iklim sosio emosional yang positif serta mengembangkan dan mempertahankan organisasi kelas yang efektif dan produktif. ${ }^{11}$ Sedangkan menurut Djamarah bahwa manajemen kelas adalah suatu kelompok orang yang melakukan kegiatan belajar bersama, yang mendapat pengajaran dari guru. $^{12}$

hal.189.

${ }^{10}$ Ghufrondimyanti.blogspot.co.id/2014/05/pengkur-9-implementasi-kurikulum.html?m=1 di akses pada hari selasa 14 januari 2020 pukul 12.44 WITA

${ }^{11}$ Mulyadi, Classroom Management: Mewujudkan Suasana Kelas yang Menyenangkan Bagi Siswa, (Malang: UIN Malang Press, 2009), hal. 4.

${ }^{12}$ Syaiful Bahri Djamarah dan Aswan Zain, Strategi Belajar Mengajar, (Jakarta: PT. Rineka Cipta, 2010), hal. 175.

Jurnal Pelangi Jurnal pemikiran dan penelitian pendidkan Islam anak Usia Dini 
Menurut Suhardan bahwa manajemen kelas adalah segala usaha yang diarahkan untuk mewujudkan suasana belajar yang efektif dan menyenangkan serta dapat memotivasi siswa untuk belajar dengan baik sesuai dengan kemampuan. Atau dapat dikatakan bahwa manajemen kelas merupakan usaha sadar untuk mengatur kegiatan proses belajar mengajar secara sistematis. ${ }^{13}$

Berdasarkan beberapa pendapat diatas dapat disimpulkan bahwa manajemen kelas adalah proses atau upaya yang dilakukan oleh seseorang guru secara sistematis untuk menciptakan dan mewujudkan kondisi kelas yang dinamis dan kondusif dalam rangka menciptakan pembelajaran yang efektif dan efisien.

\section{Ruang Lingkup Manajemen Kelas}

Ruang lingkup manajemen kelas menurut Johanna Kasin Lemlech adalah sebagai berikut;

a. Perencanaankurikulumyanglengkap mulai dari rumusan tujuannya, bahan ajarannya, sampai pada evaluasinya. Tanpa perencanaan, usaha penataan kelas tidak sebaik yang diharapkan.

b. Pengorganisasian proses belajar-mengajar dan sumber belajar sehingga serasi dan bermakna kegiatan guru dan murid diatur, sehingga terjadi interaksi yang responsive. Penataan sumber belajar akan selalu berkaitan dengan pengorganisasian proses belajar mengajar.

c. Penataan lingkungan yang bernafaskan pokok bahasan menjadi usaha guru dalam menata kelas agar kelas merangsang dan penuh dorongan untuk memunculkan proses belajar yang efektif dan efisien. ${ }^{14}$

\section{Tujuan Manajemen Kelas}

Tugas guru yang utama dalam pembelajaran adalah menciptakan suasana di dalam kelas agar terjadi interaksi belajar mengajar dengan baik dan sungguh-sungguh. Oleh sebab itu, guru dan wali kelas dituntut memiliki kemampuan yang inovatif dalam mengelola kelas. Dengan

\footnotetext{
${ }^{13}$ Dadang Suhardan, et.all, Manajemen Pendidikan, (Bandung: Alfabeta, 2009), hal.106.

${ }^{14}$ Hadi, Pengelolaan Kelas, ((Bandung, PT Rosdakarya, 2014), hal.55.
} 
pengelolaan kelas yang baik diharapkan dapat tercipta kondisi kelompok belajar yang proporsional terdiri dari lingkungan kelas yang baik yang memungkinkan siswa berbuat sesuai dengan kemampuan yang dimiliki serta tersedia kesempatan untuk mengurangi ketergantungan pada guru. Adapun tujuan manajemen kelas Menurut Wijaya bahwa tujuan manajemen kelas adalah sebagai berikut;

a. Agar pengajaran dapat dilakukan secara maksimal, sehingga tujuan pengajaran dapat dicapai secara efektif dan efisien.

b. Untuk memberi kemudahan dalam usaha memantau kemajuan siswa dalam pelajarannya. Dengan Manajemen Kelas, guru mudah untuk melihat dan mengamati setiap kemajuan/ perkembangan yang dicapai siswa, terutama siswa yang tergolong lamban.

c. Untuk memberi kemudahan dalam mengangkat masalah-masalah penting untuk dibicarakan dikelas demi perbaikan pengajaran pada masa mendatang. ${ }^{15}$

Sedangkan menurut Mudasir tujuan manajemen kelas atau pengelolaan adalah sebagai berikut:

a. Mewujudkan situasi dan kondisi kelas, baik sebagai lingkungan belajar maupun sebagai kelompok belajar.

b. Menghilangkan berbagai hambatan belajar yang dapat menghalangi terwujudnya kegiatan belajar.

c. Menyediakan dan mengatur fasilitas serta perabot belajar yang mendukung dan memungkinkan siswa belajar sesuai dengan lingkungan sosial, emosional, dan intelektual siswa di kelas.

d. Membina dan membimbing sesuai dengan latar belakang sosial, ekonomi dan budaya serta sifat individual. ${ }^{16}$

\section{Strategi Manajemen Kelas}

Upaya-upaya yang dilakukan oleh guru merupakan usaha dalam menciptakan sekaligus memelihara kondisi dan suasana belajar yang kondusif, optimal dan menyenangkan agar proses pembelajaran dapat berjalan secara efektif, sehingga tujuan pembelajaran dapat dicapai dengan maksimal. Ada beberapa strategi manajemen kelas yang

\footnotetext{
${ }^{15}$ Cece Wijaya, dkk. Kemampuan Dasar Guru Dalam Proses Belajar Mengajar, (Bandung: PT. Remaja Rosdakarya, 2012), hal.114.

${ }^{16}$ Mudasir, Manajemen Kelas, (Yogyakarta: Zanafa Publishing, 2011), hal.20.
} 
dilakukan guru dalam meningkatkan kegiatan belajar mengajar di kelas yaitu:

a. Penataan lingkungan belajar

Lingkungan belajar di kelas sebagai situasi buatan yang berhubungan dengan proses pembelajaran atau konteks terjadinya pengalaman belajar, dapat di klasifikasikan dalam lingkungan (keadaan) fisik dan lingkungan social. ${ }^{17}$ Pengelolaan lingkungan fisik meliputi penataan ruang kelas, pengaturan tempat duduk ventilasi dan pengaturan cahaya yang cukup menjamin kesehatan siswa dan pengaturan penyimpanan barang yang diatur sedemikian rupa sehingga barangbarang tersebut segera dapat digunakan. Pengelolaan lingkungan sosial meliputi interaksi guru dan siswa, siswa dengan siswa, dan siswa, guru, serta lingkungan sekitarnya. ${ }^{18}$

b. Cara pengajaran guru

Dalam rangka memelihara kondisi dan suasana belajar yang efektif, maka guru harus mampu memilih cara yang tepat dalam pelaksanaan pembelajaran. Karena mengajar adalah hal yang kompleks dan melibatkan peserta didik yang bervariasi, maka seorang pendidik harus mampu dan menguasai beragam strategi dan perspektif serta dapat mengaplikasikannya secara fleksibel. ${ }^{19}$ Dalam hal ini guru harus mampu menguasai materi pelajaran, strategi pengajaran, mempunyai keahlian manajemen kelas, keahlian motivasional, keahlian komunikasi dan dapat bekerja secara efektif dengan murid dari latar belakang cultural yang beragam.

c. Administrasi kelas

Pengelolaan administrasi kelas meliputi pengelolaan presensi yang dilakukan secara periodik, menyediakan ruangan khusus untuk keperluan bimbingan siswa yang dilakukan guru, wali kelas atau guru pembimbing sekolah, menyediakan tempat baca siswa, menyediakan tempat sampah, dan menyediakan catatan pribadi siswa sehingga guru akan mengenal siswa secara lengkap termasuk

${ }^{17}$ Milan Rianto, Pengelolaan Kelas Model PAKEM, (Jakarta: Dirjen PMPTK, 2007), hal.1.

${ }^{18}$ John W. Santrock, Terj. Tri Wibowo B.S, Psikologi Pendidikan, (Jakarta: Prenada Media Group, 2008), hal.7-8.

${ }^{19}$ Ibid,....hal .7. 
latar belakang kehidupan siswa. ${ }^{20}$

d. Pengaturan perilaku dan pemberian motivasi kepada siswa Sekolah sebagai suatu lembaga pendidikan dan lingkungan dimana siswa berinteraksi, diharapkan mampu membentuk sikap dan perilaku siswa yang baik. Dalam prosesnya, sering kali muncul perilaku siswa yang menganggu kondisi kelas. Oleh karena itu, guru dapat menerapkan sistem reward dan punishment. Reward atau penghargaan diberikan kepada siswa yang berprestasi atau berperilaku baik, dan punishment atau sanksi (hukuman) dikenakan terhadap siswa yang melanggar peraturan. Reward dan punishment berfungsi untuk menumbuhkan motivasi siswa. ${ }^{21}$

\section{Kegiatan Belajar Mengajar}

\section{Pengertian Kegiatan Belajar Mengajar}

Kegiatan belajar mengajar merupakan inti dan pelaksanaan kurikulum Baik-buruknya mutu pendidikan atau mutu lulusan dipengaruhi oleh mutu kegiatan belajar-mengajar. Menurut Wijaya bahwa kegiatan belajar mengajar adalah proses berlangsungnya kegiatan belajar dan membelajarkan siswa dikelas. Pelaksanaan pembelajaran adalah interaksi guru dan siswa dalam rangka menyampaikan bahan pelajaran kepada siswa dan untuk mencapai tujuan pembelajaran ${ }^{22}$

Pandangan lain yang sejalan dengan hal tersebut adalah yang dikemukakan oleh Ali bahwa pelaksanaan kegiatan belajar mengajar adalah pelaksanaan strategi-strategi yang telah dirancang untuk mencapai tujuan pembelajaran. Strategi, pendekatan, prinsip-prinsip dari metode pembelajaran diarahkan guna mencapai tujuan pembelajaran yang efisien dan efektif. ${ }^{23}$

Dari definisi tersebut diketahui bahwa dalam kegiatan belajar mengajar terdapat beberapa unsur diantaranya adalah pembelajaran sebagai sebuah proses yang bertujuan untuk membelajarkan siswa di

${ }^{20}$ Hadari Nawawi, Organisasi Sekolah dan Pengelolaan Kelas sebagai Lembaga Pendidikan, (Jakarta: Haji Masagung, 2004), hal.134.

${ }^{21}$ Elizabeth Hurlock, Psikologi Perkembangan: Suatu Pendekatan Sepanjang Rentang Kehidupan (Jakarta: Erlangga, 2011), hal.78.

${ }^{22}$ Cece Wijaya, dkk, Kemampuan Dasa, (Yogyakarta: Graha Ilmu, 2015), hal.23.

${ }^{23}$ Muhammad Ali, Guru Dalam Proses Belajar Mengajar, (Bandung: CV. Sinar Baru 2010), hal.124.

Jurnal Pelangi Jurnal pemikiran dan penelitian pendidkan Islam anak Usia Dini 
dalam kelas. Dalam kegiatan pembelajaran terjadi proses interaksi yang bersifat edukatif antara guru dengan siswa. Kegiatan yang dilaksanakan tersebut bermuara pada satu tujuan yaitu untuk mencapai tujuan pembelajaran yang telah ditetapkan sebelumnya.

Berdasarkan kedua pendapat di atas dapat disimpulkan bahwa kegiatan belajar mengajar adalah merupakan suatu bentuk kegiatan yang dilaksanakan oleh guru dengan siswa dengan menjalin komunikasi edukatif dengan menggunakan strategi-strategi, pendekatan, prinsip dan metode tertentu dalam rangka mencapai tujuan pembeljaaran yang efektif dan efisien berdasarkan perencanaan yang telah dibuat sebelumnya. Oleh karena itu, kegiatan kegiatan belajar mengajar harus dilaksanakan dengan baik dan optimal sehingga tujuan-tujuan pembelajaran dapat dicapai dengan baik dan optimal pula.

\section{Ciri-ciri Kegiatan Belajar Mengajar}

Sebagai suatu proses pengaturan, kegiatan belajar mengajar tidak terlepas dari ciri-ciri tertentu yang menurut Edi Suardi adalah memiliki tujuan, ada suatu prosedur (jalan interaksi) yang direncanakan, didesain untuk mencapai tujuan yang telah ditetapkan ditandai dengan suatu penggarapan materi yang khusus pada aktifitas anak didik dimana guru berperan sebagai pembimbing, membutuhkan disiplin dan ada batas waktu serta evaluasi. ${ }^{24}$

\section{Peran Guru Dalam Kegiatan Belajar Mengajar}

Kegiatan belajar mengajar tidak bisa lepas dari keberadaan guru. Tanpa adanya guru pembelajaran akan sulit dilakukan, apalagi dalam rangka pelaksanaan pendidikan formal, guru menjadi pihak yang sangat vital. Guru memiliki peran yang paling atif dalam pelaksanaan pendidikan demi mencapai tujuan pendidikan yang hendak dicapai. Guru melaksanakan pendidikan melalui kegiatan pembelajaran dengan mengajar peserta didik atau siswa.

Siswa juga akan kesulitan dalam belajar ataupun menerima materi tanpa keberadaan guru, hanya mengandalkan sumber belajar dan media

\footnotetext{
${ }^{24} \mathrm{Http}: / /$ Mahmud09 Makalah tentang Hakikat, Ciri dan Komponen Belajar, diakses pada tanggal 9 Januari 2020, jam 12.00 Wita.
} 
pembelajaran saja akan sulit dalam penguasaan materi tanpa bimbingan guru. Guru juga memiliki banyak kewajiban dalam pembelajaran dari mulai merencanakan pembelajaran, melaksanakan proses pembelajaran, hingga melakukan evaluasi pembelajaran yang telah dilakukan. ${ }^{25}$

\section{Faktor-faktor yang Mempengaruhi Kegiatan Belajar Mengajar}

Dalam hubungan dengan kegiatan belajar mengajar ini, tentunya tidak terlepas dari faktor-faktor yang mempengaruhi kegiatan belajar mengajar tersebut. Adapun faktor-faktor tersebut adalah sebagai berikut; ${ }^{26}$

a. Faktor tujuan yang ingin dicapai

Dalam melaksanakan suatu kegiatan tentunya, ada sasaran yang ingin dicapai, demikian pula halnya dengan pendidikan itu sendiri. Adapun tujuan yang ingin dicapai disini adalah dari pengetahuan, keterampilan dan sikap serta nilai-nilai.

b. Faktor materi pelajaran

Untuk terlaksananya interaksi edukatif atau proses belajar mengajar, maka materi pelajaran merupakan salah satu faktor yang menentukan. Pokok bahasan untuk setiap bidang studi mempunyai nilai-nilai tertentu sangat perlu dicapai dalam setiap proses belajar mengajar. $^{27}$

c. Faktor-faktor sumber belajar.

Dalam proses belajar mengajar, maka yang merupakn sumber belajar disini yaitu segenap bahan-bahan dan alat-alat yang bisa menunjang dalam kelangsungan proses belajar mengajar serta bagaimana relefansinya dengan materi pelajaran yang diajarkan. Sumber belajar disini penulis dapat mengungkapkan antara lain : alat peraga, bukubuku paket, lingkungan sekitar termasuk masyarakat. Pengajaran akan mencapai hasil yang optimal bila didasarkan atas interaksi yang baik anata murid dengan lingkungan sekitarnya, serta masyarakat.

d. Keadaan Siswa

Terlaksananya proses belajar mengajar apabila ada subyek siswa

${ }^{25}$ Sardiman, Peran Guru Dalam Proses Belajar Mengajar, (Jakarta: Aziik. wordpress. com, 2018), diakses pada tanggal 9 Januari 2020, jam 10.23 Wita.

${ }^{26} \mathrm{Ibid}, \ldots . .$. hal.139-140.

${ }^{27} \mathrm{Ibid}, \ldots .$. hal.141.

Jurnal Pelang̉i Jurnal pemikiran dan penelitian pendidkan Islam anak Usia Dini 
sebagai obyek belajar mengajar itu sendiri. Dalam uraiannya mengenai keadaan siswa, maka penulis hanya akan mengungkapkan secara garis besarnya hal-hal yang mempengaruhi siswa dalam proses belajarnya. Adapun faktor tersebut yaitu faktor intern dan ekstern. Faktor intern misalnya : kemampuan, minat dan perhatian, kebiasaan, motivasi serta usaha dan lain sebagainya. Sedangkan faktor eksternal misalnya : lingkungan keluarga sekolah dan masyarakat.

e. Keadaan guru

Guru juga merupakan faktor kedua setelah anak didik. Guru dalam proses belajar mengajar mentransferkan pelajaran kepada anak didik atau siswa, sehingga terjadi interaksi edukatif yang selaras. Dalam interaksi edukatif, seorang guru mengetahui, sebagai fungsi dan kedudukannya. Menurut Sardiman AN, sehubungan dengan fungsi guru, maka harus dituntut untuk memiliki aspek-aspek sebagai berikut;

1) Guru harus dapat memahami dan menempatkan kedewasaanya, sebagai pendidik harus mampu menjadikan dirinya sebagai teladan.

2) Guru harus mengenal dirinya sendiri, bukan hanya mengenal sifat dan kebutuhanya secara umum sebagai sebuah kategori, bukan saja mengenai jenis minat, kemampuan, cara belajar, tetapi harus mengenai bakat, minat, kebutuhan, pribadi serta aspirasi masingmasing anak didik.

3) Guru harus memiliki kecakapan memberi bimbingan kepada anak didik.

4) Guru harus memiliki dasar pengetahuan yang luas tentang tujuan pendidikan di Indonesia pada umumnya.

5) Guru harus memiliki pengetahuan yang bulat dan baru mengenai ilmu yang diajarkan.

6) Keadaan kelas, jumlah siswa dan waktu yang tersedia.

\section{METODOLOGI PENELITIAN}

Jenis penelitian ini menggunakan jenis penelitian kualitatif. Menurut Moleong bahwa metodologi kualitatif sebagai prosedur penelitian yang menghasilkan data deskriptif berupa kata-kata tertulis atau lisan dari 
orang-orang dan perilaku yang dapat diamati. ${ }^{28}$

Sumber data dan teknik pengumpulan data dimaksudkan dalam penelian adalah subyek dari mana dapat diperoleh. Adapun sumber data yang dipergunakan dalam pengusunan skripsi ini yaitu; (1) Data Primer. Data primer adalah data yang didapat secara langsung dari objek penelitian seperti; kepala sekolah dan 2 (dua) orang guru TK Negeri 08 Penatoi Kota Bima, (2) Data Sekunder. Data sekunder adalah data yang diperoleh atau dikumpulkan oleh orang yang melakukan penelitian dari sumber-sumber yang telah ada. Data sekunder dalam penelitian ini seperti; buku-buku, majalah-majalah koran dan lain-lain. ${ }^{29}$ Adapun teknik pengumpulan data dalam penelitian ini seperti; metode observasi, dimana peneliti melakukan pengamatan terhadap objek yang diteliti. ${ }^{30}$ Selanjutnya, metode wawancara (Interview) dimana peneliti melakukan interview kepada pihak sekolah dengan tujuan agar mendapatkan informasi. ${ }^{31}$ Kemudian metode dokumentasi. Metode dokumentasi yaitu mencari data mengenai hal-hal atau variabel yang berupa catatan, transkrip, buku, surat kabar, majalah, prasasti, notulen rapat, legger, agenda dan sebagainya. ${ }^{32}$

Instrumen penelitian. Adapun instrumen yang digunakan untuk mengumpulkan data penelitian ini adalah; (1) Pedoman Observasi. Pedoman observasi merupakan metode pengumpulan data dengan melakukan pengamatan data terhadap objek yang diteliti. (2) Pedoman Wawancara. Pedoman wawancara yaitu sejumlah pertanyaan lisan dengan maksud penelitian dan dipergunakan atau dipertanyakan kepada orang yang menjadi sampel dalam penelitian ini yaitu kepala sekolah dan guru di Tk Negeri 08 Penatoi Kota Bima, (3) Pedoman Dokumentasi. Pedoman dokumentasi yaitu alat yang digunakan untuk memperoleh berbagai data yang diperlukan oleh peneliti yang terkait dengan lokasi penelitian di TK Negeri 08 Penatoi Kota Bima.

Teknik Analisis Data . Adapun teknik analisis data yang digunakan dalam penelitian ini adalah Analisis Kualitatif. Metode analisis dilakukan

${ }^{28}$ Lexy J.Moleong, Metodologi Penelitian Kualitatif, (Bandung : PT. Remaja Rosdakarya, 2006), hal.32.

${ }^{29} \mathrm{Ibid}, \ldots .$. hal.275.

${ }^{30} \mathrm{Ibid}, . .$. hal.120.

${ }^{31}$ Sutrisno Hadi, Metodologi Reseach, (Jakarta: Sinar Grafika, 2005), hal.25.

${ }^{32}$ Suharsimi Arikonto, Prosedur Penelitian Suatu Pendekatan Praktek, (Jakarta: PT. Rineka Cipta, 2010), hal.31.

Jurnal Pelang̉i Jurnal pemikiran dan penelitian pendidkan Islam anak Usia Dini 
dengan tiga cara yaitu; ${ }^{33}$ (1) Pengumpulan Data. Pengumpulan data dalam penelitian ini seperti; mencatat semua data secara obyektif dan apa adanya sesuai dengan hasil observasi dan wawancara di lapangan. (2) Reduksi Data. Reduksi data dapat diartikan sebagai proses pemilihan, pemusatan perhatian, dan penyederhanaan data yang dicatat dalam catatan lapangan dalam jumlah yang cukup banyak. Dalam proses reduksi data, tahapan yang peneliti lakukan adalah seleksi, memilih data yang relevan dan bermakna, menyederhanakan dan mengabarkan hal-hal yang penting tentang hasil temuan yang berkenaan dengan permasalahan penelitian yang direduksi.(3) Verifikasi Data. Verifikasi data merupakan kesimpulan awal masih bersifat sementara, dan akan berubah bila tidak ditemukan bukti-bukti yang kuat yang mendukung pada tahap pengumpulan data berikutnya.

Pengujian Kredibilitas Data. Dalam penelitian ini, pemeriksaan kredibilitas data didasarkan pada kriteria-kriteria tertentu untuk menjamin validitas data yang diperoleh melalui penelitian. Uji kredibilitas data dalam penelitian kualitatif meliputi uji, kredibilitas, transferabilitas, dependabilitas, dan konfirmabilitas. Akan tetapi dalam penelitian ini hanya kredibilitas. Kredibilitas data dimaksudkan untuk membuktikan data yang berhasil dikumpulkan sesuai dengan dunia nyata serta terjadi dengan sebenarnya. Untuk mencapai nilai kredibilitas ada beberapa yang digunakan yaitu tehnik tringulasi, pengecekan anggota, perpanjangan kehadiran, diskusi dengan guru yang bersangkutan dan pengecekan kecukupan referensi. ${ }^{34}$ Adapun langkah-langkah yang dilakukan oleh peneliti dalam mencari kebenaran data yaitu sebagai berikut: ${ }^{35}$ (1) Member check (cek berulang-ulang). Member check adalah kegiatan mencek kebanaran data yang dilakukan oleh peneliti setelah mengumpulkan semua data yang valid. Kegiatan ini dilakukan oleh peneliti agar data yang dikumpulkan tidak diragukan lagi kebenarannya. (2) Cross Check. Cross check adalah kegiatan yang dilakukan oleh peneliti untuk melihat kebenaran terhadap data yang telah dikumpulkan dari hasil observasi, wawancara dan dokumentasi di lokasi penelitian TK Negeri

${ }^{33}$ Sugiyono, Metode Penelitian Kuantitatif, Kualitatifdan RED, (Bandung: Alfabeta, 2013), hal.247.

${ }^{34}$ Ibid,......hal.270.

${ }^{35}$ Amirul Hadi \& Haryono, Metodologi Penelitian Pendidikan, (Bandung: CV. Pustaka Setia, 1998), hal.205. 
08 Penatoi Kota Bima, Kegiatan ini dilakukan oleh peneliti agar tidak terjadi kesalahan terhadap data yang telah dikumpulkan oleh peneliti di lapangan. (3)Triangulasi. Triangulasi adalah teknik pemeriksanaan keabsahan data yang memanfaatkan sesuatu yang lain di luar data itu untuk keperluan pengecekan atau sebagai pembanding terhadap data itu. Adapun triangulasi yang digunakan adalah triangulasi sumber dan triangulasi metode. Triangulasi sumber dilakukan dengan maksud untuk mendapatkan informasi yang sejenis dari informasi atau sumber lain yang berbeda. Untuk melaksanakan triangulasi sumber yang dilakukan terhadap sesuatu yang menjadi fokus penelitian.

\section{HASIL DAN PEMBAHASAN}

\section{Implementasi Manajemen Kelas dalam Kegiatan Belajar Mengajar di TK Negeri 08 Penatoi Kota Bima}

Berdasarkan hasil observasi awal yang dilakukan oleh peneliti terkait dengan implementasi manajemen kelas dalam kegiatan belajar mengajar di Taman Kanak-Kanak 08 Penato'i Kota Bima ialah dengan melakukan perencanaan terkait program tahunan, semester, harian kemudian mingguan. ${ }^{36}$

“Menurut Ibu Rukayah, selaku Kepala Sekolah TK Negeri 08 Penatoi Kota Bima, Secara umum sebelum program dimulai terlebih dahulu saya buat rancangan program untuk dibahas bersama yang kemudian rancangan program tersebut dilokakaryakan, sehingga ada penambahan kebutuhan sekolah, karena tugas bagi guru memberikan pelayanan pada murid-murid dengan sebaik-baiknya. Kemudian mengenai perencanaan dikelas, masing-masing diserahkan kepada wali kelas tersebut untuk mengkoordinir sendiri pelaksanaannya" ${ }^{37}$

Dari hasil wawancara diatas dapat disimpulkan bahwa sebelum program dimulaiakan dibahas terlebih dahulu kemudian dilokakaryakan, sehingga adanya penambahan kebutuhan sekolah terkait dengan program yang dirancang. Kemudian perencanaan dikelas masingmasing akan diserahkan kepada setiap wali kelas untuk mengkoordinir

\footnotetext{
${ }^{36}$ Hasil Observasi di TK Negeri 08 Penatoi Kota Bima pada tanggal 23 Oktober 2019 pukul 08.30 .

${ }^{37}$ Hasil wawancara dengan Ibu Rukayah, Tanggal 23 Desember 2019, Jam 09.13 Wita.
}

Jurnal Pelang̉i Jurnal pemikiran dan penelitian pendidkan Islam anak Usia Dini 
sendiri pelaksanaannya.

“Senada juga apa yang diungkapkan oleh Ibu Kartini selaku guru kelas Mengenai perencanaan manajemen kelas disini, saya sebagai guru mengajak semua guru berunding supaya anak-anak di kelas tidak merasan bosan saat KBM berlangsung dan merasa sangat mudah dan tidak merasakan kesulitan. Perencanaan yang di ambil itu mulai dari metode belajar, media dan sumber belajar, penataan kelas dan yang lainnya bersamaan dengan keefektivitasan kelas tersebut. Itu yang menjadi rencana awal belajarnya" ${ }^{38}$

Dari pemaparan diatas mengenai manajemen kelas guru di Taman Kanak-kanak Negeri 08 Penatoi melakukan perundingan terlebih dahulu terkait dengan metode belajar yang akan digunakan, media dan sumber belajar, penataan kelas dan yang lainnya terkait dengan keefektivitasan kelas tersebut. Cara ini dilakukan agar anak merasa nyaman dan memahami dengan baik bahan ajar yang akan diajarkan. Hal yang sama juga diucapkan oleh Ibu ST. Ramlah mengatakan bahwa;

“Sekolah Taman Kanak-kanak Negeri 08 Penatoi Kota Bima sudah melakukan kurikulum berbasis K13, karena K13 sangat sesuai dengan kebutuhan peserta didik pada saat ini. Dalam pembuatan Rencana Pelaksanaan Pembelajaran Mingguan (RPPM) diturunkan dari PROTA, POSEM, RPPM, dan RPPH, yang berisikan sub tema, kompetensi Dasar (KD), materi, dan rencana kegiatan, penyusunan RPPM akan disesuaikan dengan strategi pengelolaan kelas( klasikal, area, sudut, kelompok usia dan sentra) hal tersebut sudah ditetapkan oleh masingmasing satuan PAUD". ${ }^{39}$

Dari uraian diatas dapat disimpulkan bahwa sebelum melakukan kegiatan pembelajaran guru terlebih dahulu menyiapkan perangkat pembelajaran atau bahan ajar yang berupa PROTA, PROSEM, RPPM, dan RPPH yang berisikan sub tema, Kompetensi Dasar (KD), materi, dan rencana kegiatan yang akan disusun sesuai dengan strategi pengelolaan kelas. Kemudian jika perencanaan sudah dilakukan maka selanjutnya pelaksanaan pembelajaran yang terdiri dari kegiatan pembuka, inti dan penutup kemudian terakhir melakukan evaluasi terkait pelaksanaan yang dilakukan.

\footnotetext{
${ }^{38}$ Hasil wawancara dengan Ibu Kartini, Tanggal 23 Desember 2019, Jam 09.40 Wita.

${ }^{39}$ Hasil wawancara dengan Ibu ST. Ramlah, Tanggal 24 Desember 2019, Jam 10.20 Wita.
} 


\section{Implementasi Manajemen Kelas dalam Kegiatan Belajar Mengajar di TK Negeri 08 Penatoi Kota Bima}

Pelaksanaan atau implementasi, dalam Kamus Besar Bahasa Indonesia diartikan sebagai pelaksanaan atau penerapan. Sedangkan menurut Fullan dalam Abdul Majid implementasi adalah suatu prooses peletakan dalam praktik tentang suatu ide, program atau seperangkat aktivitas baru bagi orang lain dalam mencapai atau mengharapkan suatu perubahan. ${ }^{40}$ Di Taman Kanak-Kanak Negeri 08 Penatoi Kota Bima sebelum program pembelajaran dimulai, akan dibahas terlebih dahulu kemudian dilokakaryakan, sehingga adanya penambahan kebutuhan sekolah terkait dengan program yang dirancang. Kemudian perencanaan dikelas masing-masing akan diserahkan kepada setiap wali kelas untuk mengkoordinir sendiri pelaksanaannya.

Guru di Taman Kanak-kanakNegeri08Penatoi melakukan perundingan terlebih dahulu terkait dengan metode belajar yang akan digunakan, media dan sumber belajar, penataan kelas dan yang lainnya terkait dengan keefektivitasan kelas tersebut. Cara ini dilakukan agar anak merasa nyaman dan memahami dengan baik bahan ajar yang akan diajarkan.

Upaya-upaya yang dilakukan oleh guru merupakan usaha dalam menciptakan sekaligus memelihara kondisi dan suasana belajar yang kondusif, optimal dan menyenangkan agar proses pembelajaran dapat berjalan secara efektif, sehingga tujuan pembelajaran dapat dicapai dengan maksimal. Ada beberapa strategi manajemen kelas yang dilakukan guru dalam meningkatkan kegiatan belajar mengajar di kelas yaitu;

\section{a. Penataan lingkungan belajar}

Lingkungan belajar di kelas sebagai situasi buatan yang berhubungan dengan proses pembelajaran atau konteks terjadinya pengalaman belajar, dapat di klasifikasikan dalam lingkungan (keadaan) fisik dan lingkungan sosial. ${ }^{41}$ Pengelolaan lingkungan fisik meliputi penataan ruang kelas, pengaturan tempat duduk ventilasi dan pengaturan cahaya yang cukup menjamin kesehatan siswa dan pengaturan penyimpanan barang yang

${ }^{40}$ Abdul Majid, Implementasi Kurikulum 2013 Kajian Teoritis dan Praktis, (Bandung: Interes Media, 2014), hal.6.

${ }^{41}$ Milan Rianto, Pengelolaan Kelas Model PAKEM, (Jakarta: Dirjen PMPTK, 2007), hal.1.

Jurnal Pelang̉i Jurnal pemikiran dan penelitian pendidkan Islam anak Usia Dini 
diatur sedemikian rupa sehingga barang-barang tersebut segera dapat digunakan. Pengelolaan lingkungan sosial meliputi interaksi guru dan siswa, siswa dengan siswa, dan siswa, guru, serta lingkungan sekitarnya. ${ }^{42}$

\section{b. Cara pengajaran guru}

Dalam rangka memelihara kondisi dan suasana belajar yang efektif, maka guru harus mampu memilih cara yang tepat dalam pelaksanaan pembelajaran. Karena mengajar adalah hal yang kompleks dan melibatkan peserta didik yang bervariasi, maka seorang pendidik harus mampu dan menguasai beragam strategi dan perspektif serta dapat mengaplikasikannya secara fleksibel. ${ }^{43}$ Dalam hal ini guru harus mampu menguasai materi pelajaran, strategi pengajaran, mempunyai keahlian manajemen kelas, keahlian motivasional, keahlian komunikasi dan dapat bekerja secara efektif dengan murid dari latar belakang cultural yang beragam.

\section{c. Administrasi kelas}

Pengelolaan administrasi kelas meliputi pengelolaan presensi yang dilakukan secara periodik, menyediakan ruangan khusus untuk keperluan bimbingan siswa yang dilakukan guru, wali kelas atau guru pembimbing sekolah, menyediakan tempat baca siswa, menyediakan tempat sampah, dan menyediakan catatan pribadi siswa sehingga guru akan mengenal siswa secara lengkap termasuk latar belakang kehidupan siswa. ${ }^{44}$

\section{d. Pengaturan perilaku dan pemberian motivasi kepada siswa}

Sekolah sebagai suatu lembaga pendidikan dan lingkungan dimana siswa berinteraksi, diharapkan mampu membentuk sikap dan perilaku siswa yang baik. Dalam prosesnya, sering kali muncul perilaku siswa yang menganggu kondisi kelas. Oleh karena itu, guru dapat menerapkan sistem reward dan punishment. Reward atau penghargaan diberikan kepada siswa yang berprestasi atau berperilaku baik, dan punishment atau sanksi (hukuman) dikenakan terhadap siswa yang melanggar peraturan.

\footnotetext{
${ }^{42}$ John W. Santrock, Terj. Tri Wibowo B.S, Psikologi Pendidikan, (Jakarta: Prenada Media Group, 2008), hal.7-8.

${ }^{43}$ Ibid,....hal. 7.

${ }^{44}$ Hadari Nawawi, Organisasi Sekolah dan Pengelolaan Kelas sebagai Lembaga Pendidikan, (Jakarta: Haji Masagung, 2004), hal.134.
} 
Reward dan punishment berfungsi untuk menumbuhkan motivasi siswa. ${ }^{45}$

Dalam melakukan perencanaan ada beberapa program yang disusun oleh guru di Taman Kanak-Kanak 08 Penatoi Kota Bima ialah menyiapkan perangkat pembelajaran atau bahan ajar yang berupa Program Tahunan (PROTA), Program Semester (PROSEM), Rencana Program Pemebelajaran Mingguan (RPPM), dan Rencana Program Pembelajaran Harian (RPPH) yang berisikan sub tema, Kompetensi Dasar (KD), materi, dan rencana kegiatan yang akan disusun sesuai dengan strategi pengelolaan kelas. Kemudian jika perencanaan sudah dilakukan maka selanjutnya pelaksanaan pembelajaran yang terdiri dari kegiatan pembuka, inti dan penutup kemudian terakhir melakukan evaluasi terkait pelaksanaan yang dilakukan.

Setara dengan hasil wawancara diatas adapun tahap-tahan implementasi yaitu;

1) Pengembangan program, yaitu mencakup program tahunan, semester, bulanan, mingguan dan harian. Selain itu juga ada program bimbingan dan konseling atau program remedial.

2) Pelaksanaan pembelajaran, pada hakekatnya, pembelajaran adalah proses interaksi antara peserta didik dengan lingkungannya sehingga terjadi proses perubahan perilaku kearah yang lebih baik.

3) Evaluasi, yaitu proses yang dilaksanakan sepanjang proses pelaksanaan kurikulum atau semester serta penilaian akhir formatif atau sumatif mencakup penilaian keseluruhan secara utuh untuk keperluan evaluasi pelaksanaan kurikulum. ${ }^{46}$

\section{KESIMPULAN}

Dari hasil penelitian yang telah dipaparkan terkait dengan implementasi manajemen kelas di Taman Kanak-Kanak Negeri 08 Penatoi Kota Bima, maka penulis dapat mengambil kesimpulan bahwa; 1. Implementasi manajemen kelas dalam proses belajar mengajar di TK Negeri 08 Penatoi Kota Bima dilakukan oleh Guru ialah dengan

${ }^{45}$ Elizabeth Hurlock, Psikologi Perkembangan: Suatu Pendekatan Sepanjang Rentang Kehidupan (Jakarta: Erlangga, 2011), hal.78.

${ }^{46}$ Ghufrondimyanti.blogspot.co.id/2014/05/pengkur-9-implementasi-kurikulum.html?m=1 di akses pada hari selasa 14 januari 2020 pukul 12.44 WITA

Jurnal Pelangi Jurnal pemikiran dan penelitian pendidkan Islam anak Usia Dini 
tahap awal melakukan perencanaan terhadap program yang akan dilaksanakan yaitu; Menyusun Program Tahunan (PROTA), Program Semester (PROSEM), Rencana Program Pembelajaran Mingguan (RPPM), dan Rencana Program Pembelajaran Harian $(\mathrm{RPPH})$ yang yang berisikan; Tema dan Sub tema, Kompetensi Dasar (KD), Materi, Rencana kegiatan yang akan disusun sesuai dengan strategi pengelolaan kelas. Kemudian jika perencanaan sudah dilakukan maka selanjutnya pelaksanaan pembelajaran yang terdiri dari kegiatan pertama kegiatan pembuka, kedua kegiatan inti dan terakhir kegiatan penutup.

\section{DAFTAR PUSTAKA}

Ali Muhammad, 2010, Guru Dalam Proses Belajar Mengajar, Bandung: CV. Sinar Baru.

Arikonto Suharsimi, 2010, Prosedur Penelitian Suatu Pendekatan Praktek, Jakarta: PT. Rineka Cipta,

Depdiknas, 2005, Undang-Undang Sistim Pendidikan Nasional, Jakarta: Depdiknas.

Djamarah Bahri Syaiful \& Zain Aswan, 2010, Strategi Belajar Mengajar, Jakarta: PT. Rineka Cipta.

Elrais Heppy, 2015, Kamus Ilmiah Populer,Bandung: Interes Media.

Fathurrohman Muhammad \& Sulistyorini, 2012, Implementasi manajemen Peningkatan Mutu Pendidikan Islam Peningkatan Lembaga Pendidikan Islam Secara Holistik, Yogyakarta: Teras.

Ghufrondimyanti.blogspot.co.id/2014/05/pengkur-9-implementasi kurikulum.html?m=1 di akses pada hari selasa 14 januari 2020 pukul 12.44 WITA

Hadi Amirul \& Haryono, 1998, Metodologi Penelitian Pendidikan, Bandung: CV. Pustaka Setia.

Hadi Sutrisno, 2005, Metodologi Reseach, Jakarta: Sinar Grafika.

Hadi, 2014, Pengelolaan Kelas, Bandung: PT Rosdakarya.

Harsanto Radno, 2007, Pengelolaan Kelas yang Dinamis, Yogyakarta: KANISIUS.

Hasil Observasi di TK Negeri 08 Penatoi Kota Bima pada tanggal 23 Oktober 2019 pukul 08.30. 
Hasil wawancara dengan Ibu ST. Ramlah, Tanggal 24 Desember 2019, Jam 10.20 Wita.

Hasil wawancara dengan Ibu Kartini, Tanggal 23 Desember 2019, Jam 09.40 Wita.

Hasil wawancara dengan Ibu Rukayah, Tanggal 23 Desember 2019, Jam 09.13 Wita.

Hermino Agustinus, 2014, Kepemimpinan Pendidikan di Era Globalisasi, Yogyakarta: Pustaka Pelajar.

Http://Mahmud09 Makalah tentang Hakikat, Ciri dan Komponen Belajar, diakses pada tanggal 9 Januari 2020, jam 12.00 Wita.

Hurlock Elizabeth, 2011, Psikologi Perkembangan: Suatu Pendekatan Sepanjang Rentang Kehidupan Jakarta: Erlangga.

Hurlock Elizabeth, 2011, Psikologi Perkembangan: Suatu Pendekatan Sepanjang Rentang Kehidupan Jakarta: Erlangga.

Majid Abdul, 2014, Implementasi Kurikulum 2013 Kajian Teoritis dan Praktis, Bandung: Interes Media.

Majid Abdul, 2014, Implementasi Kurikulum 2013 Kajian Teoritis dan Praktis, Bandung: Interes Media.

Moleong J Lexy, 2006, Metodologi Penelitian Kualitatif, Bandung: PT. Remaja Rosdakarya.

Mudasir, 2011, Manajemen Kelas, Yogyakarta: Zanafa Publishing.

Mulyadi, 2009, Classroom Management: Mewujudkan Suasana Kelas yang Menyenangkan Bagi Siswa, Malang: UIN Malang Press.

Nawawi Hadari, 2004, Organisasi Sekolah dan Pengelolaan Kelas sebagai Lembaga Pendidikan, Jakarta: Haji Masagung.

Nawawi Hadari, 2004, Organisasi Sekolah dan Pengelolaan Kelas sebagai Lembaga Pendidikan, Jakarta : Haji Masagung.

Observasi di TK Negeri 08 Penatoi Kota Bima Tanggal 13 Mei 2019, jam 08.20 Wita.

Rianto Milan, 2007, Pengelolaan Kelas Model PAKEM, Jakarta: Dirjen PMPTK.

Santrock W John, Terj. B.S Wibowo Tri, 2008, Psikologi Pendidikan, Jakarta: Prenada Media Group.

Sardiman, Peran Guru Dalam Proses Belajar Mengajar, Jakarta: Aziik. wordpress. com, 2018), diakses pada tanggal 9 Januari 2020, jam 10.23 Wita.

Jurnal Pelang̉i Jurnal pemikiran dan penelitian pendidkan Islam anak Usia Dini 
Sugiyono, 2013, Metode Penelitian Kuantitatif, Kualitatifdan RED, Bandung: Alfabeta.

Suhardan Dadang, et.all, 2009, Manajemen Pendidikan, Bandung: Alfabeta. Wijaya Cece, dkk, 2015, Kemampuan Dasa, Yogyakarta: Graha Ilmu.

Wijaya Cece, dkk, 2012, Kemampuan Dasar Guru Dalam Proses Belajar Mengajar, Bandung: PT. Remaja Rosdakarya. 